\title{
Comments on "The Sdom evaporite formation in Israel and its relationship with the Messinian Salinity Crisis" by J. Charrach
}

\author{
P. Möller ${ }^{1} \cdot$ E. Rosenthal ${ }^{2} \cdot$ C. Siebert ${ }^{3}$
}

Accepted: 21 February 2019 / Published online: 1 March 2019

๑) Springer-Verlag GmbH Germany, part of Springer Nature 2019

\begin{abstract}
According to J. Charrach, the Sdom formation is a major non-marine evaporite sequence deposited during the climax of the Mediterranean Salinity Crisis (MSC). Hydrochemical studies, however, reveal that the evaporites of the Sdom and Zemah stratigraphic columns dominantly originate from evaporated Tethys seawater mixed with some local drainage water. The formation of evaporites in the northern and southern Inland Sea lasted about $2 \mathrm{Ma}$, a period that could only be pre-Messinian, i.e., most probably Tortonian.
\end{abstract}

Keywords Inland Sea $\cdot$ Sdom formation $\cdot$ Duration of evaporation $\cdot$ Messinian Salinity Crisis

\section{Introduction}

The Inland Sea, also called Sdom Sea or Sdom Lagoon, spread over the Jordan Dead Sea transform (Rift) from north of Lake Tiberias to south of the Dead Sea. There are controversial ideas about the duration of its existence and the source(s) of its brines. Various scenarios of brine formation in the Rift were suggested such as (i) seawater penetration from the Tethys into the Rift through the Yizre'el-HarodBet She'an valley (Mazor and Mero 1969; Gat et al. 1969; Magaritz and Nadler 1980; Bergelson et al. 1999; Möller et al. 2012), (ii) formation of $\mathrm{Mg}^{2+}$-rich brines in the Sdom depression (Starinsky 1974), (iii) ablation of post-halite evaporites (Flexer et al. 2000) and (iv) upflow of deep-seated Triassic brines (Rosenthal 1988a, b). Klein-BenDavid et al. (2004) proposed a dual-mode evaporation system in which the one-basin Inland Sea was connected to the Tethys either by inflow and outflow or only by inflow.

Recently, two widely opposing scenarios were published the results of which will be critically compared below. In J.

P. Möller

pemoe@gfz-potsdam.de

1 Helmholtz Centre Potsdam, German Research Centre for Geosciences GFZ, Section 3.4, Potsdam, Germany

2 The School of Earth Sciences, Tel Aviv University, Tel Aviv, Israel

3 Department Catchment Hydrology, UFZ-Helmholtz Centre for Environmental Research, Halle, Germany
Charrach's (2018) view "the Sdom Fm is...considered to represent a major non-marine evaporite sequence equivalent in time to the Upper Evaporite Messinian Fm of the Mediterranean (5.6-5.5 Ma)". His hypothesis is based on (i) tectonic arguments, (ii) the sequence of evaporites in each cycle and (iii) general hydrochemical considerations. A contrary view emerged from the simulation of the evaporation of a mixture of seawater and drainage water leading to the Sdom and Zemach halite deposits of essentially marine origin in the Rift (Möller et al. 2018). The estimated time spans of evaporation revealed that about $2 \mathrm{Ma}$ were necessary to deposit the thick evaporate sequence known from the Sdom and Zemah drill cores in the southern and northern Rift, respectively. The simulations were calibrated to $\mathrm{Na} / \mathrm{Cl}=0.12$ and 0.5 of the final brines in the southern basin (artesian Sdom 1 and the wells Lot 1 and Emunah 1) and the northern basin (the fresh water diluted Ha'On and Tiberias Hot Spring brines) (Möller et al. 2014).

\section{Can the Sdom Fm be contemporaneous with the climax of MSC?}

Charrach assumes that the Sdom Fm was contemporaneous with the climax of the Messinian Salinity Crisis (MSC) because this was the only period of intense aridity in the area and both events should be of the same age interval. This is in no way conclusive because evaporation might also have progressed under humid conditions which of course 
needed much more time. In our recently published simplified simulations of the evaporation of a mixture of Tethys seawater and drainage water in the Rift under enhanced humidity were compared to the presence and assumed constant inflow of Tethys water and backflow of brine at depth of the spillway. Chemical changes in groundwater of the northern and southern Rift revealed a barrier at Marma Feiyad which led to three phases of evaporation in the Rift depending on the Tethys sea level relative to the height of the barrier in the Rift. In phase 1, only the northern basin was flooded by Tethys water invading through the Yizre'el Valley. During enhanced stands of the Tethys in phase 2, the northern and southern basins were inundated and in phase 3 again only the northern basin was inundated by seawater due to low stands of the Tethys. In the northern basin, evaporites were formed during phases 1 and 3 . In phase 2, evaporites were deposited only in the southern basin because the inflow of Tethys seawater prevented halite deposition in the northern basin. The Tethys seawater is continuously evaporated and mixed with more saline water from below on its way from the Qishon graben towards the southern basin in the Rift. The halite deposition of the Sdom Fm came to an end when the inflow from the northern basin ceased. The thick Zemach evaporites of phase 3 are younger than the Sdom ones of phase 2. Each of these phases lasted about 0.7 Ma and thus the Inland Sea existed for about $2 \mathrm{Ma}$. This large time span is owed to the open system in which seawater invaded and brines left the system comparable with the situation in the Straits of Gibraltar (Möller et al. 2018).

\section{Is a period of evaporation of $10^{5}$ years reasonable?}

The average subsidence of the rift of about $14 \mathrm{~km}$ (BenAvraham 2014) during 20-16 Ma (Garfunkel 1997, 2014) yields a rate of $700-875 \mathrm{~m} / \mathrm{Ma}$. Following Charrach, the deposition of about $1000 \mathrm{~m}$ evaporites of the Sdom Fm during postulated $10^{5}$ years had to be compensated by a subduction rate of $10 \mathrm{~km} / \mathrm{Ma}$. If at Zemah $2074 \mathrm{~m}$ marine sediments should have been accumulated in the assumed period, it accounts for an average subduction rate of $20.7 \mathrm{~km} / \mathrm{Ma}$, which is even more unlikely than that of the Sdom Fm. It may be argued that the whole pile of Zemah sediments, deposited on the flank of a dome (Inbar 2012) could have been enlarged by sloping of sediments. However, thickening by a factor of 20 is highly unlikely. Their deposition cannot have occurred during the narrow time window of $10^{5}$ years suggested by Charrach (2018).

The time span of about 2 Ma does neither fit the window between the end of MSC and the appearance of the Cover Basalt (5.3-4.6 Ma) nor between the intermediate and Cover
Basalts (6.2-5.6 Ma). The realistic position in the stratigraphic column could only be pre- or post-Messinian.

The evaporites of the Mavqi'im Fm in the Messininan indicate that at that time there was no inflow of water from the Tethys into the Rift (Charrach 2018). This disproves the existence of the Inland Sea to be post-Messinian as suggested by Horowitz (2001) who placed the Inland Sea into the early Pliocene by palynozonal studies. A pre-Messinian period of the Inland Sea could have been terminated by the beginning of the MSC at about 6.3 Ma. Based on this event, the Inland Sea existed between 8.5 and 6.3 Ma, i.e., during the Tortonian (Möller et al. 2018).

\section{Sr isotopes}

Compared to the average total drainage flux during the Tortonian of the order of $10^{9} \mathrm{~m}^{3} / \mathrm{a}$, which is significantly more than at present (Möller et al. 2018), the brine flux into the southern basin is only about half of the drainage flux. Due to higher Sr concentration in seawater than in runoff and groundwater, the contribution of $\mathrm{Sr}$ of the former dominated in the Inland Sea water.

The argument that ${ }^{87} \mathrm{Sr} /{ }^{86} \mathrm{Sr}$ values from Ryan (2008) and Flecker and Elam (2006) representing the ratios of the Tethys evaporites during MSC are in about the same range as the ratios of evaporites from the Sdom Fm (Stein 2000), is true but not convincing that they are of similar age, i.e., of "Upper Messinian Evaporite Fm". The ${ }^{87} \mathrm{Sr} /{ }^{86} \mathrm{Sr}$ values in the Sdom Fm are 0.7085 (Sdom Deep 1 borehole, Stein et al., 2000) and are lower than the Messinian and Tortonian seawater with 0.7089 and $0.7087-0.7089$, respectively (Burke et al. 1982). Considering that the Jordan-Dead Sea Rift is mainly enclosed by Cretaceous limestones with ${ }^{87} \mathrm{Sr} /{ }^{86} \mathrm{Sr}$ values of $0.7074-0.7076$ (Stein et al. 2000; Stein et al. 2002) and by some igneous/metamorphic rocks on the Jordanian side, the subaerial and subsurface drainage water transported Sr into the Sdom Sea which was mainly leached from Cretaceous limestones. In the Inland Sea, brines from both sources with different ${ }^{87} \mathrm{Sr} /{ }^{86} \mathrm{Sr}$ values were mixed yielding values of about 0.7085 (Sdom Deep 1 borehole; Stein et al. 2000). Contribution of $\mathrm{Sr}$ from continental sources yields lower ${ }^{87} \mathrm{Sr} /{ }^{86} \mathrm{Sr}$ values than those of contemporaneous Tethys water.

\section{Non-marine vs marine origin of evaporites}

Continental water, unaffected by marine brines or evaporates, show molar ratios of $\mathrm{Na} / \mathrm{Cl}>1$ (ref. lake water and brines in Eugster and Hardie 1978; Jones and Deocampo 2003). Thus, mixtures of continental runoff and 
groundwater with increasing amounts of halite dissolution brines trend towards $\mathrm{Na} / \mathrm{Cl}=1$.

Contrasting, evaporation of modern seawater with $\mathrm{Na} /$ $\mathrm{Cl}$ of about 0.85 (a similar value may be assumed for the Tortonian Tethys) yields $\mathrm{Na} / \mathrm{Cl}$ brines as low as 0.12 in the southern basin. Such low $\mathrm{Na} / \mathrm{Cl}$ values are known from brines in wells Lot 1 and Emunah 1 and from the artesian Sdom 1, all in the Dead Sea area (Möller et al. 2014). In mixtures of seawater brines with halite dissolution brines, the low values of $\mathrm{Na} / \mathrm{Cl}<1$ finally increase towards $\mathrm{Na}$ / $\mathrm{Cl}=1$. The low $\mathrm{Na} / \mathrm{Cl}$ values of 0.12 in the southern and 0.5 in the northern basin clearly refer to evaporation system in which $\mathrm{Na}^{+}$and $\mathrm{Cl}^{-}$were dominated by seawater. These low $\mathrm{Na} / \mathrm{Cl}$ values of terminal brines are neither related to brines from the Lisan Fm nor the Holocene Dead Sea. The low $\mathrm{Na} / \mathrm{Cl}$ ratio in the Dead Sea of about 0.23 is the result of the presence of residual brines from the Inland Sea and Lake Lisan being leached from adjacent sedimentary rocks. The evaporites of the Sdom formation (Gardosh et al. 1997) and Zemah core (Marcus and Slager $1985)$ are dominantly of marine origin.

\section{Precipitation of $\mathrm{K}$ and $\mathrm{Mg}$ salts}

Sylvite precipitates from seawater brine after having reached $\mathrm{Na} / \mathrm{Cl}$ of 0.12 . To conserve sylvite, it is necessary that inflow of drainage water should not mix with the bottom brines in the basin, which is only possible in basins of considerable depths. Thus, the presence of sylvite proves a basin-like scenario. Small variations either in evaporation rates or supply of preconcentrated seawater from the northern basin may explain the cyclicity of $\mathrm{NaCl}$ and $\mathrm{KCl}$ described by Charrach (2018).

Continental drainage mainly from terrains built of limestones is generally poor in $\mathrm{Mg}^{2+}$. Thus the absence of $\mathrm{Mg}^{2+}$ salts was considered by Charrach (2018) as an argument against seawater evaporation in the Rift. Sylvite precipitates earlier than $\mathrm{Mg}^{2+}$ salts which derive only from seawater brines of $\mathrm{Na} / \mathrm{Cl}<1.2$. Such low values are not reported from deep drillings near the Dead Sea. Thus, the absence of $\mathrm{Mg}$ salts does not prove the absence of seawater in the evaporation system of the Rift.

\section{Conclusions}

The hydrochemical arguments suggest that the evaporites of the Sdom and Zemah stratigraphic column originate from mixtures of evaporated Tethys seawater and drainage water. The evaporites are dominantly of marine origin. Neither ${ }^{87} \mathrm{Sr} /{ }^{86} \mathrm{Sr}$ nor the absence of $\mathrm{Mg}$ salts proves the major non-marine source of evaporites proposed by Charrach. The evaporation events of the Sdom Fm in the southern basin and at Zemah in the northern basin were neither contemporaneous nor were they deposited during the climax of MSC within $10^{5}$ years. Due to enhanced humidity during the Tortonian the existence of the Inland Sea with variable N-S extension lasted more than $2 \mathrm{Ma}$ in agreement with an average subsidence rate of 700-875 m/ Ma. Three phases of seawater inundation and evaporation occurred. In phase 1, only the northern part of the rift was affected. In phase 2, the whole rift was flooded but halite deposition took place only in southern basin separated from the northern by a barrier allowing only the surface brines to flow into the southern basin. In phase 3 , again only the northern one was flooded and the Zemach evaporites were deposited. It is suggested that the evaporation events occurred during the Tortonian and ceased with the beginning of the Messinian salinity crisis.

Open Access This article is distributed under the terms of the Creative Commons Attribution 4.0 International License (http://creativeco mmons.org/licenses/by/4.0/), which permits unrestricted use, distribution, and reproduction in any medium, provided you give appropriate credit to the original author(s) and the source, provide a link to the Creative Commons license, and indicate if changes were made.

\section{References}

Ben-Avraham Z (2014) Geophysical studies of the crustal structure along the Southern Dead Sea Fault. In: Garfunkel Z, Ben-Avraham Z, Kagan E (eds) Dead Sea transform fault system: reviews. Springer, Berlin, pp 1-27

Bergelson G, Nativ R, Bein A (1999) Salinisation and dilution history of groundwater discharging into the Sea of Galilee, the Dead Sea transform, Israel. Appl Geochem 14:91-118

Burke WH, Denison RE, Hetherington EA, Koepnick RB, Nelson $\mathrm{HF}$, Otto JB (1982) Variation of seawater ${ }^{87} \mathrm{Sr} /{ }^{86} \mathrm{Sr}$ throughout Phanerozoic time. Geology 10:516-519

Charrach J (2018) The Sdom evaporite formation in Israel and its relationship with the Messinian Salinity Crisis. Carbonate Evaporite. https://doi.org/10.1007/s13146-017-0410-1

Eugster HP, Hardie LA (1978) Saline lakes. In: Lerman A (ed) Lakes-chemistry, geology, physics. Springer, New York, pp 237-293

Flecker R, Elam RM (2006) Identifying Late Miocene episodes of connection and isolation in the Mediterranean-Paratethyan realm using Sr isotopes. Sediment Geol 188-189:189-203

Flexer A, Yellin-Dror A, Kronfeld E, Rosenthal E, Ben Avraham Z, Artzstein PP, Davidson L (2000) A Neogene salt body as the primary source of the salinity in Lake Kinneret. Arch Hydrobiol Spec Issue Adv Limnol 55:69-85

Gardosh M, Kashai E, Salhov S, Shulman H, Tannenbaum E (1997) Hydrocarbon exploration in the Dead Sea area. In: Niemi TM, Ben-Avraham Z, Gat JR (eds) The Dead Sea. Oxford University Press, New York, pp 57-72

Garfunkel Z (1997) The history of the formation of the Dead Sea basin. In: Niemi TM, Ben-Avraham Z, Gat JR (eds) The Dead Sea. Oxford University Press, New York, pp 36-56 
Garfunkel Z (2014) Lateral motion and deformation along the Dead Sea Transform. In: Garfunkel Z, Ben-Avraham Z, Kagan E (eds) Dead Sea transform fault system: reviews. Springer, Dordrecht, pp 109-150

Gat JR, Mazor E, Tzur Y (1969) The stable isotope composition of mineral water in the Jordan Rift Valley. J Hydrol 16:177-211

Horowitz A (2001) The Jordan rift valley. Chapter 7.2 the paleogeography. Sweets and Zeitlinger B.V, Lisse, pp 331-362

Inbar N (2012) The evaporitic subsurface body of Kinnarot basin: stratigraphy, structure, geohydrology. PhD thesis. English. Tel Aviv University, Israel, p 133

Jones BF, Deocampo DM (2003) Geochemistry of saline lakes. In: Holland HD, Turekian KK (eds) Treatise on Geochemistry, vol 5. Elsevier, Amsterdam, pp 393-424

Magaritz M, Nadler A (1980) Re-interpretation of ${ }^{18} \mathrm{O}$ and D isotopic composition of the Tiberias subgroup hot waters. Proc. Geol. Isr. Ann Meet Southern Sinai and the Gulf of Elat, Ophira, Sinai, Feb 1980, pp 1-26

Marcus E, Slager J (1985) The sedimentary-magmatic sequence of the Zemah 1 well (Jordan-Dead Sea Rift, Israel) and its emplacement in time and space. Isr J Earth Sci 34:1-10

Mazor E, Mero F (1969) Origin of the Kinneret-Noit water association in the Kinneret-Dead Sea Valley. Isr J Hydrol 7:318-333

Möller P, Siebert C, Geyer S, Inbar N, Rosenthal E, Flexer A, Zilberbrand M (2012) Relationship of brines in the Kinnarot Basin, Jordan-Dead Sea Rift Valley. Geofluids 12:166-181

Möller P, Rosenthal E, Flexer A (2014) The hydrogeochemistry of subsurface brines in and west of the Jordan-Dead Sea Transform fault. Geofluids 14:291-309
Möller P, Rosenthal E, Inbar N, Siebert C (2018) Development of the Inland Sea and its evaporites in the Jordan-Dead Sea Transform based on hydrogeochemical considerations and the geological consequences. Int J Earth Sci 107:2409-2431. https:// doi.org/10.1007/s00531-018-1605-y

Rosenthal E (1988a) Hydrogeochemistry of groundwater at unique outlets of the Bet Shean multiple aquifer system. Isr J Hydrol 97:75-87

Rosenthal E (1988b) Ca-chloride brines at common outlets of the Bet Shean-Harod multiple aquifer system. Isr J Hydrol 97:89-106

Ryan WBF (2008) Modeling of magnitude and timing of evaportaive drawdown during the Messinian salinity crisis. Stratigraphy 5:227-243

Starinsky A (1974) Relationships between Ca-chloride brines and sedimentary rocks in Israel. PhD thesis, Department of Geology, Hebrew University, Jerusalem

Stein M, Starinsky A, Agnon A, Katz A, Raab M, Spiro B, Zak I (2000) The impact of brine-rock interaction during marine evaporite formation on the isotopic $\mathrm{Sr}$ record in the oceans: evidence from $\mathrm{Mt}$ Sedom, Israel. Geochim Cosmochim Acta 64:2039-2053

Klein-BenDavid O, Sass E, Katz A (2004) The evolution of marine evaporitic brines in inland basin: the Jordan-Dead Sea Rift Valley. Geochim Cosmochim Acta 68:1763-1775

Publisher's Note Springer Nature remains neutral with regard to jurisdictional claims in published maps and institutional affiliations. 